\title{
ОСНОВНІ НАПРЯМИ ДІЯЛЬНОСТІ ШКІЛЬНИХ СОЦІАЛЬО-ПЕДАГОГІЧНИХ СЛУЖБ УКРАЇНИ (ПОЧАТОК ХХ СТОЛІТТЯ)
}

\section{Боярська-Хоменко А. В.}

доктор педагогічних наук, доцент, в. о. завідувача кафедри освітології та інноваційної педагогіки, Харківський національний педагогічний

університет імені Г. С. Сковороди,м. Харків, Україна

\section{Кузнецова О. Ю.}

доктор педагогічних наук, професор, завідувач кафедри іноземних мов №3, Національний юридичний університет імені Ярослава Мудрого,

м. Харків, Україна

\section{Штефан Л. А.}

доктор педагогічних наук, професор, професор кафедри освітології та інноваційної педагогіки, Харківський національний педагогічний університет імені Г. С. Сковороди, м. Харків, Україна

У статті визначено і проаналізовано провідні напрями діяльності шкільних сочіально-педагогічних служб України на початку XX століття. Установлено, щз до їх складу входили класні керівники, працівники педологічної служби, представники осередків "Друзі дітей», які праиювали в таких напрямах як: колективне виховання дітей; взаємодія з сім'єю; організачія дозвілля дітей.

Ключові слова: напрям діяльності, сочіально-педагогічна служба, школа.

The leading directions of activities of school social and pedagogical services of Ukraine in the early XX century are determined and analysed. The research findings suggest that the leading activities dealt with collective education of children, interaction with the family and organization of children's leisure. The structure of school social and pedagogical services consisting of class teachers, "pedological" service staff and representatives of the communities called "Friends of Children" is characterized.

Key words: direction of activities, school social and pedagogical service, school.

Вивчення та узагальнення нормативних матеріалів свідчить про те, що до загальноосвітніх закладів початку XX століття належали різні типи шкіл, а саме: трудова школа з семирічним терміном навчан- 
ня; школи робітничої молоді; досвідні і зразкові школи; українські, російські, єврейські та ін. До складу шкільних соціально-педагогічних служб в окреслений період належали класні керівники, педологічні працівники, представники друзів дітей та організатори дозвіллєвої сфери.

Необхідно наголосити на тому, що інститут класного керівника офіційно було засновано в 30-ті рр. ХХ століття. У 20-ті рр. ХХ століття виховну роботу з учнями молодшої школи проводив один учитель, у старших класах — усі педагоги, котрі працювали з учнями [5].

Педологічні працівники на початку XX століття працювали в переважній більшості шкіл України. Зазначені працівники основну увагу приділяли питанням вивчення учнів. До складу педологічних працівників належали: педолог, лікар, керівник школи і керівники молодших та старших класів.

Представники осередків «Друзі дітей» також проводили активну соціально-педагогічну діяльність у школах. Зокрема, вони займалися питаннями залучення громадськості до справи допомоги дітям, охорони здоров'я учнів, збереження їхніх прав, надання школярам індивідуальної матеріальної допомоги. До складу представників осередку входили педагоги, батьки школярів, учні старшого віку [1, с. 188].

Аналіз науково-педагогічних даних дає підстави сформулювати мету соціально-педагогічної діяльності в школах на початку XX століття, яка передбачала вдосконалення дитячої особистості шляхом позитивного впливу на шкільне, сімейне середовище й особистість окремого учня.

Зазначена мета досягалась шляхом розв'язання певних завдань, ЯК-ОТ:

- сприяння формуванню дитячого колективу, виявлення суспільної активності учнів;

- забезпечення успішної взаємодії школи та родини;

- організація дозвілля школярів;

- підготовка учнів до свідомого вибору професії;

- сприяння успішній соціалізації дітей, котрі потребують особливої уваги й допомоги.

Окреслені завдання знайшли своє втілення в провідних напрямах діяльності шкільних соціально-педагогічних служб на початку ХХ століття. 
Так, до першого напряму діяльності зазначених служб можна віднести організацію колективного виховання учнів.

Суттєвий внесок в розробку питань обгрунтування поняття колективу, визначення типів дитячих колективів та методики їх вивчення зробив відомий педолог досліджуваного періоду - О. Залужний. Під колективом науковець розумів «групу осіб, які спільно реагують на ті чи інші подразники» [4, с.59].

Взагалі, як свідчить аналіз праць ученого, О. Залужний визначав п'ять типів дитячих колективів. Перший тип - самовиниклі короткочасні колективи. До цього типу належали колективи, котрі створювались для виконання будь-якої дії (наприклад, прибирання шкільної ділянки), або колективи, які виникли під час прогулянки та ін. Ці колективи виникали без належних інструкцій і існували недовго.

До другого типу належали самовиниклі довготривалі колективи. Ці колективи утворювалися переважно за симпатіями. До них можна віднести вуличні компанії дітей, об’єднання безпритульних та різних правопорушників й ін.

Третій тип включав організовані, але короткотривалі колективи. До таких колективів належали організовані спілки, збори, з'їзди та ін. Зазначені колективи відрізнялися від неорганізованих тим, що їх поведінка описувалась інструкцією чи існуючими правилами.

До четвертого типу дитячих колективів можна віднести організовані довготривалі прості (начальні групи, шкільні кооперативи, гуртки тощо).

До п’ятого типу — організовані довгочасні складні — належали всі колективи, котрі складались із більш простих об’єднань. Це: піонерські спілки, будинки дитячої творчості та ін.

Надзвичайно важливими для шкільних соціально-педагогічних працівників О. Залужний уважав дитячі колективи четвертого типу. Науковець розробив систему діагностики колективу цього типу, котра включала вивчення загальної поведінки групи в залежності від впливу оточення та ситуації; поведінки, що зумовлена виховними інструкціями; організованості та складу групи; рівня успішності групи в шкільній роботі [3]. Фахівець слушно наголошував, що вивчати колективи дітей «можливо лише в динаміці, в їхньому зародженні, розвитку та розкладі» [4, с.59].

Організовуючи колективне виховання учнів, представники шкільної соціально-педагогічної служби широко використовували такі фор- 
Розділ III. Історичні та порівняльні аспекти в теорії і практиці духовно-інтелектуального виховання й навчання ми організації колективу, як-от учнівське самоврядування та дитячі громадські об'єднання.

Фактично в усіх школах України на початку XX століття були створені органи учнівського самоврядування. Що стосується змісту зазначеної діяльності фахівці соціально-педагогічного профілю виконували діагностичну, організаційну, координуючу та консультаційну функції.

Соціально-педагогічний працівник проводив діагностику організованості дитячого колективу, визначав лідерів серед школярів, перевіряв зміст та характер їхньої роботи. Також проводилось вивчення «важких дітей» у школі, дітей, що випадали із дитячого колективу, виявляли надзвичайно низький рівень свідомості в шкільній діяльності $[2$, c.35].

Організаційну функцію в основному виконував класний керівник, частково керівник загальноосвітнього закладу. Саме зазначені фахівці визначались із структурою учнівського самоврядування та залучили школярів до його органів.

Як свідчить проведене дослідження, організаційне навантаження на соціально-педагогічних працівників у кожній школі було різним та визначалося рівнем розвитку дитячого колективу. Якщо клас відзначався високим рівнем організованості, то організаційна функція соціально-педагогічного працівника змінювалась на координаційну, котра полягала в координації роботи загальношкільних і класних органів учнівського самоврядування та ін. Консультаційна функція передбачала надання порад і рекомендацій педагогом органам учнівського самоврядування щодо змісту роботи в школі та поза нею.

До головних напрямів діяльності шкільних соціально-педагогічних служб також належала і робота із сім’єю школяра.

Велику увагу вчені приділяли питанням вивчення шляхів педагогізації родини. Так, О. Шахрай до зазначених шляхів відносила обстеження родини на дому, проведення педагогічної консультації у різних установах — яслах, дитсадках, школах, спілкування на педагогічні та санітарно-гігієнічні теми на батьківських зборах [6, с. 26]. Дослідниця також наголошувала на необхідності створення при школах педагогічної консультації.

До визначених шляхів педагогізації родини А. Тер-Гевондян додала ще залучення батьків до роботи в Комітетах Сприяння, шкільних 
комісіях, у комісіях трудової допомоги школі, участь батьків у батьківських зборах, видавництві шкільної газети для батьків, створення в школах спеціальних кімнат для батьків.

Велику увагу шкільні соціально-педагогічні служби приділяли педагогічному керівництву дозвіллям дітей. Провідними суб'єктами означеної діяльності виступали організатори дозвіллєвої сфери, класні керівники та керівники гуртків.

Отже, у загальноосвітніх школах України початку ХХ століття соціально-педагогічні служби складались із класних керівників, працівників педологічної служби, представників осередку «Друзі дітей». Вони якісно працювала в таких напрямах як: колективне виховання дітей; взаємодія з сім'єю школяра; організація дозвілля дітей.

\section{Список використаних джерел:}

1. Баран-Бутович П. Г. 3 практики громадсько-корисної роботи в школі. Шлях освіти. 1930. № 11-12. С. 185-189.

2. Волобуєв П. Організуймо педологічну роботу в школі. Політехнічна школа. 1932. № 8-9. С. 30-36.

3. Залужний О. Дитячий колектив й оточення. Шлях освіти. 1925. № 3-4. С. 89-97.

4. Залужний О. Учення про колектив. Методологія - дитколектив. Х., 1928. $86 \mathrm{c}$.

5. Кодекс законов о народном просвещении УССР. Х.: Издание Народного комиссариата просвещения УССР,1922. 75 с.

6. Шахрай О. Педагогізація родини. Радянська освіта. 1929. № 1. С. 25-28. 